\title{
Study on the Development Status of China's Agriculture International Trade and Prospects
}

\author{
Xianghui Xu \\ Zhengzhou Institute of Science and Technology, Zhengzhou Henan, 450064, China
}

Keywords: Agriculture international trade, Development status, Prospect

\begin{abstract}
With the continuous development of global economic integration, exchanges between China and the world increasingly close, especially in economic development, in the process of development of international trade in agriculture, although made more remarkable achievement, but the problems are growing prominent presence of such a situation, the development of agriculture in international trade China has a very negative impact, therefore, to take effective measures to resolve the issues is very necessary. In this paper, the current situation of China's agricultural development of international trade conducted in-depth analysis on the existing problems of the measures proposed solutions, and on this basis, describes the development trend of China's international trade in agriculture, for reference.
\end{abstract}

\section{Introduction}

China is a large agricultural country, the agricultural economy larger proportion in the national economy, since China's accession to the WTO, the international trade of agricultural development faster and faster, but at the same time, the existing problems are gradually exposed, under such circumstances, how to effectively solve the agricultural problems of international trade has become the focus of attention.

\section{Status of China's agriculture international trade}

\section{Infrastructure to be perfected}

China's current actual situation, China's capital investment in agricultural infrastructure construction to be strengthened, especially farmland water conservancy facilities and so on. Through practical research can be found in the southwestern provinces of agricultural infrastructure in some areas is not perfect, but there are still existing function of aging facilities and the structure is not complete and other issues, these problems, so that this part of agriculture to resist natural the relatively low level of disaster, agricultural development is lagging behind. And because the terrain in southern China are complex and lead to inadequate transportation facilities, market facilities are relatively backward, there are these two issues, resulting in sales of agricultural products as well as the southern part of the region is very difficult to transport, agricultural enterprises cannot achieve the scale of operations [1]. Through the above content aware, China's current agricultural infrastructure is not perfect, resulting in agriculture do not have a strong ability to withstand natural disasters, and cannot meet the demand for capital and technology greatly dependent.

\section{Low level of agriculture science and technology}

In recent years, science and technology development of China's agriculture has made a more significant effect, but compared with developed countries, there is still a big gap, resulting in a lot of reasons for such a situation occurs, for example, our research work on agricultural technology the support is not enough, our farmers affected by the traditional concept of planting more serious, skeptical of new technology and research personnel in accordance with a fixed idea of research and development technology, no technological innovation, these factors are leading to a lower level of China's agricultural science and technology the main reason. In addition, the technical staff developed a new technology and there is no promotion at the first time to the countryside to promote the work place, but also one of the factors affecting the level of China's agricultural science and technology improvement. The above information on the development of agricultural science and 
technology of China has a restraining effect, leading our country into the international market; there are no higher value-added agricultural products.

\section{Trade barrier}

Trade barriers are composed of two parts, the part of the tariff barriers, and the other part is the non-tariff barriers. The so-called tariff barriers, refers to the relevant departments need to charge higher tariffs and surcharges, etc., and refers to the non-tariff barriers on agricultural products by the relevant departments of quota restrictions ways to control the number of agricultural products into the market, at the same time, the implementation of Mandatory import licensing system also led to China's agricultural products cannot get a fair chance to compete for the factors. Related departments by charging high tariffs and other ways to control the number of agricultural products flowing into the domestic market, although this measure can protect their own agriculture to some extent, but it violates the principle of equality of trade, which not only limits the country's health development, but also to foreign agricultural enterprises had a negative impact, although non-tariff barriers and tariff barriers used in different ways, but its purpose is the same, are not desirable behavior [2]. In addition, widespread use of green barriers in developed countries, the developed countries on the requirements of safety, health and other aspects of agricultural products is very high, and our agricultural enterprises did not pay attention to these areas, which led to China's agricultural green barriers cannot even pass, their number is very small.

\section{Developed countries abuse subsidy policy}

In order to promote the development of domestic agriculture in developed countries, to develop a high subsidies, developed countries starting point of this policy is good, but in the actual application, but because of the abuse of this policy cause problems workings of the international market of agricultural products competition is no longer fair and impartial. In addition, high subsidies, although in the short term can promote the development of domestic agriculture, but will find that after long-term use, this policy reduces the competitiveness of agricultural products, and the government over-intervention in the agricultural market competition, will lead to its resource allocation function is not sound, leading companies can not get a foothold in the brutal competition.

\section{Concrete measures to solve the problems of international trade development of China's agriculture}

\section{Adjust agricultural structure, and strengthen the advantages of agricultural exports}

On the current situation of China's agricultural development, the agricultural structure is unscientific, structural problems, the development of agriculture national trade has a negative impact, and therefore, the agricultural structure adjustment is very necessary. Adjustment of agricultural structure cannot be blindly, we need to market and consumer demand all learn to adjust, based on the international market but also should understand the requirements for agricultural products, improve the quality of their own agricultural products, from packaging, quality and grade so the whole aspects of the comprehensive package of agricultural products, and to improve their competitiveness [3]. At the same time, the advantage should strengthen agricultural exports. Want to make China's agricultural products to obtain a foothold in the international market, they should focus on supporting low production costs, quality assurance and agricultural development with Chinese characteristics, advantages only strengthen agricultural exports, in order to occupy a certain market share in international trade, thus promoting the development of China's agricultural economy.

\section{Improve China's agricultural management system}

In recent years, even though China has gradually increased emphasis on agricultural development, but due to various factors, resulting in our existing agricultural management system is not perfect, the existence of such a situation, to accelerate the pace of China's agricultural development have a negative impact. Therefore, the relevant departments must be based on China's national conditions and the actual situation of agricultural development, the gradual improvement of agricultural management system, establish the times, and to the development of the market has in-depth study of the Governing Body, established with the support of agriculture on the basis of production supervision system. 


\section{Strengthen scientific and technological development and strengthen agricultural infrastructure construction}

Science and technology are primary productive forces, we want to promote the development of agriculture, increase in the international trade market competitiveness of our agricultural products, we must strengthen the scientific and technological development. National Agricultural Science and Technology should give full support to the researchers, you can put all their energy to the study of agricultural technology. Agricultural technology researchers in the course of the study, should be looking for a new angle, starting from the new breakthrough research, innovation and research only constant in order to ensure that developed the technology is advanced. When the researchers will study new technologies come out, extension staff must do the promotion, the new technology transfer to farmers, improve the quality of agricultural products from the source [4]. At the same time, the state should vigorously develop agricultural infrastructure construction, improve farmers' living environment, and improve their standard of living, thus promoting economic development in rural areas.

\section{Strengthen "standardized" production consciousness}

China's agricultural products processing enterprises still relatively small scale, but more dispersed, the lack of leading enterprises, including the case of agricultural products to China to compete in the international market has a negative impact is, in view of this situation, should establish a scientific and rational agricultural product quality standard system, in developing this system in the process, we should focus on pillar industries, and to develop products with local characteristics, at the same time, it should be divided according to region, to create a regional brand, a brand advantage, which can improve the competitiveness of agricultural products in China.

\section{Improve agriculture protection policy}

Making process of multilateral trade negotiations, China should pay attention to the treatment of countries with market economies and should be talking about this issue as much as possible the process of fighting for the interests, in order to change the injustices suffered by China's agricultural products in international trade. At the same time, the state also should follow the rules of foreign trade on the basis of ongoing changes in agricultural protection policy, which can promote the development of agriculture.

\section{Accelerate the construction of agricultural international trade promotion system}

In the international trade market increasingly competitive situation, China should accelerate the construction of agricultural trade promotion system, in the process of building this system, you should consider China's national conditions, and are not contrary to WTO rules, the only way to promote China's economic the stability and development.

\section{Promote overseas investment cooperation}

Want to improve the agricultural level, it should be innovation and cooperation, and promote cooperation and development of overseas investment. In the process of cooperation, we can learn at their own advantages, to retain its own characteristics, while the advanced experience and technology to its own experience with technology integration, thus promoting the modernization of the agricultural economy. At the same time, we should improve the tax system, which can further promote the development of international trade in agricultural products.

\section{Development trend of China's agriculture international trade}

\section{Import and export trade of China's agricultural products will continue to rise}

In recent years, in the case of China's economic opening-up, China's import and export trade of agricultural products continued to rise. Through the analysis of the external environment it can be seen after the country joined the WTO, signed related agreements with the import and export of agricultural products and after that the positive obligation to fulfill its own, but also further open up markets for agricultural products. Through analysis of the internal environment can be seen, China is on the current market economic structure adjustment, the adjustment process, the supply and demand of agricultural products has undergone tremendous change, quality of life has been significantly improved, the per capita consumption the amount has also been significant growth, these changes 
have positive significance in promoting the development of China's agricultural trade and, therefore, in the next period of time, China's import and export trade of agricultural products will continue to rise.

\section{Labor-intensive agricultural products is the development trend}

Livestock and horticultural products are, along with the requirements for green products continues to increase in developed countries, China is also bound to join the labor-intensive industries to green products within the scope of the fray, we want to stand out in the ranks, and we must take effective measures to improve agricultural production, at the same time, solve the problems of food quality and safety, ensure the export trade of agricultural products is high quality, non-hazardous. Want to improve the quality of agricultural products, on the one hand should introduce and implement food safety standards, and improve quarantine regime; on the other hand should give full play to the advantages of labor-intensive industries, accelerate the pace of the occupation of international trade market. Cotton and soybeans and other land-intensive products, the production of these products is relatively small scale farmers, competitiveness is relatively weak, and the current market demand for such products and large, these cases indicate that the land-intensive agricultural products gradually lost competitive advantage, therefore, become the new advantages of labor-intensive agricultural products, wants to promote the development of agriculture, we must vigorously develop labor-intensive agricultural products [5].

\section{Green trade is the development trade of international agricultural trade}

Green pollution-free agricultural products is an upgraded version of the product, compared to the more stringent standard and pollution-free agricultural standards must be in accordance with standard procedures and the use of specialized production methods of production, and after the production is completed, the need for specialized inspection agency certification, after which quality standards are allowed to use the logo of green products, such products have a non-polluting, high-quality, health, and security advantages. After the current international trade by market research found that the amount of import and export trade of agricultural products rising at the same time, sales of green products is also gradually increase, and its development trend is more rapid, have occupied more and more market, but also some agricultural exports to the United States, Japan and other countries and regions, such a situation clearly showing that the competitiveness of China's green products in gradually. Export of green products, the most important are grain and oil and vegetables, etc., and exports a large amount of area is in the coastal and northeastern provinces, which can be seen, in terms of our green product quality, brand and price increasingly significant advantages, such a situation has fully demonstrated in the next stage, the green trade will be one of the main trend of the development of agriculture in international trade, and its prospects are very bright.

\section{Conclusions}

To sum up, China's international trade in agriculture, although after the ups and downs in the course of development, but our efforts to overcome difficulties and find their market is bright. China has joined the WTO, to provide an opportunity for China to further open the door, but at the same time, the development of agricultural products in China is also facing serious challenges. Therefore, in our country at the same time open their own, should learn from foreign advanced experience, and to develop science and technology research enterprise, innovation and agricultural technology, to promote the further development of agricultural science and technology, and thus produce more and better quality agricultural products, to improve our agricultural products international trade competitiveness, and promote the overall development of China's agricultural economy.

\section{References}

[1] Wang Jiang, Xiao Hua. Dilemma in international trade development under trade equalization perspective and solutions. Business Economics Research, 2014(11):26-27. 
[2] Miao Jinfeng, Zheng Xianwei, Tan Binbin. China's agricultural international trade development strategic choice based on fair trade. Agricultural economy, 2015(4):115-118.

[3] Wang Guoyong. China's agricultural international trade improvement countermeasures. Scientific and technical information, 2012(24):105-106.

[4] Zhang Yuchen. The status, problems and development strategy of China's agricultural products trade. Legal institution and economy(mid-month episode),2013(8):84-85.

[5] Chen Xuhua. Empirical research on China's food international trade competitiveness situation and influence factors - based on GR analytical method.The Price, 2014(5):88-91 